\title{
Business and development strategies in China: inferences based on the evolution of SINOPEC
}

Estratégias empresariais e de desenvolvimento na China:
inferências baseadas na evolução da SINOPEC
1. Mestre em Desenvolvimento Econômico pelo Instituto de Economia da Universidade Estadual de Campinas. Professora Assistente e coordenadora do curso de Ciências Econômicas da Universidade Federal Rural do Rio de Janeiro (UFRRJ). Bolsista de Extensão no País SA. Foi bolsista do IPEA (PRO-MOB) no projeto "Estrutura Socioeconômica e Políticas para a Integração da América do Sul". Participou do projeto "Perspectivas do Investimento no Brasil" (BNDES) com o tema "Perspectiva do Investimento na dimensão do Mercosul e da Integração da América Latina. ORCID ID : 0000-0002-4824-8414

2. Economista, doutor em Economia pela Universidade Federal Fluminense (UFF/RJ). Atualmente é professor Associado II do curso de Ciências Econômicas da Universidade Federal Rural do Rio de Janeiro (UFRRJ) e do Programa de Pós-graduação em Economia Regional e Desenvolvimento (PPGER/UFRRJ).

Membro do Conselho Consultivo do Centro Brasileiro de Solidariedade aos

Povos e Luta pela Paz (CEBRAPAZ). ORCID ID: 0000-0003-4550-8564

\author{
Rubia Cristina Wegner ${ }^{1}$ \\ Marcelo Pereira Fernandes ${ }^{2}$
}

DOI: 10.5752/P.2317-773X.2021v9.n1.p70

Received on: January 05, 2020

Accepted on: May 25, 2020

\begin{abstract}
The purpose of this paper is to present Sinopec in the context of the transformations of property organization in China, especially the constitution of the business sector under long-term national development strategies. A hypothesis is that the growth of a large state-owned enterprise in China is on the one hand, the benefits of state support and on the other, the constraints imposed by such benefits on its business strategies of profitability and efficiency. In order to confirm this hypothesis, we analyze the evolution of the oil and gas sector in China, from the point of view of the formation of its large companies. Next, Sinopec indicators, relate to the company's financial development and strategies, are analyzed for the period 1999 to 2016 . We sought to highlight the evolution of the company's indicators compared to the national strategies adopted. Results show that Sinopec remains dependent on the national economic development strategies.
\end{abstract}

Keywords: Chinese company. Sinopec. Oil and gas industry. Multinational enterprise. National development.

\section{RESUMO}

O objetivo deste artigo é apresentar a SINOPEC, avaliada como sendo a maior empresa chinesa, no contexto das transformações, na China, da organização da propriedade, especialmente, a constituição do setor empresarial sob as estratégias nacionais de desenvolvimento de longo prazo. Uma hipótese aventada é que o crescimento de uma grande empresa estatal na China está sob uma força de dupla direção: de um lado, os benefícios do suporte estatal e de outro as restrições desses benefícios sobre suas estratégias empresariais de lucratividade e eficiência. Para tanto, primeiro se analisa retrospectivamente a evolução do 
setor de petróleo e gás na China do ponto de vista da formação de suas grandes empresas. Em seguida, são analisados indicadores da SINOPEC para o período de 1999 a 2016. Indicadores esses relacionados à evolução financeira e estratégias da empresa - incluindo de mercado, de produção e de inovação. Procura-se destacar a evolução dos indicadores da empresa comparativamente as estratégias nacionais que foram sendo adotadas. Dentre os resultados, está que a SINOPEC mesmo com todo o crescimento experimentado, mantém-se muito dependente das estratégias de desenvolvimento econômico nacional traçadas pelo Conselho de Estado.

Palavras-chave: Empresa chinesa. Sinopec. Indústria de óleo e gás. Multinacional. Desenvolvimento nacional.

\section{RESUMEN}

El objetivo de este estudio es presentar la SINOPEC, que se considera la compañía china más grande, en el contexto de los cambios en la organización de la propiedad en China, especialmente la constitución del sector empresarial chino bajo sus estrategias nacionales de desarrollo a largo plazo. Una hipótesis es que el crecimiento de una gran empresa estatal en China se encuentra bajo una fuerza doble: por un lado, los beneficios del apoyo estatal y, por otro, las limitaciones de esos beneficios en sus estrategias comerciales de rentabilidad y eficiencia. Con este fin, primero analizamos retrospectivamente la evolución del sector de petróleo y gas de China desde el punto de vista de la formación de sus grandes empresas. Los indicadorsaúde la SINOPEC luego se analizan para el período de 1999 a 2016. Estos indicadores están relacionados con la evolución financiera y com las estrategias de la compañía, incluyendo mercado, producción e innovación. Buscamos resaltar la evolución de los indicadores de la compañía en comparación con las estrategias nacionales que se adoptaron. Entre los resultados, SINOPEC, a pesar de todo el crecimiento experimentado, sigue siendo muy dependiente de las estrategias nacionales de desarrollo económico esbozadas por el Consejo de Estado.

Palabras clave: Sinopec. Industria del petróleo y el gas. Multinacional. Desarrollo nacional

\footnotetext{
"Certamente, o que está sendo aplicado no nosso país é o sistema de economia de mercado socialista. Devemos desenvolver a superioridade do nosso sistema socialista e o papel ativo do Partido e do governo. O fato do mercado desempenhar o papel decisivo na alocação de recursos não significa que o mesmo tenha toda responsabilidade"

Xi Jinping
}

Introduction

Historically, a multinational company can be considered a cell of the development model and of the international competitive strategy of its home country. Despite having their own strategies, multinational companies cannot be analyzed as isolated agents in the international 
system of trade and investment. Major internationalization movements were initiated from multinational corporations - for example, the fragmentation of production in the 1980s - which were backed by national governments. Since it changed its Constitution, inserting the term "market socialism with Chinese characteristics" in the early 1980s, the State Council of China built large companies in pillar industries, such as iron and steel, and oil and gas, which greatly expanded their presence abroad from the first years of the 21st century, when the Chinese going out strategy began. These changes were made based one a series of reforms in the property regime, innovation law, regulation of foreign investment, tax reform, banking system, etc.

Academic studies on the so-called "Chinese presence" are recurrent, i.e., on the influx of direct investment of Chinese companies in developing countries (OKAZAKI ET AL, 2011; CINTRA, 2013; PINTO; CINTRA, 2015). In general, these studies are characterized by the investigative concern to determine the weight of Chinese long-term economic development interests in the strategies of their multinational companies. While its place as the arm of the Chinese state bureaucracy is only analyzed in terms of an opposition between Market Economy and Command Economy. It is from this perspective that business in China is usually considered as a process in formation, especially by multilateral organizations, whose final result will only occur with privatization and/or opening to foreign competition. In this country, the large international Chinese state enterprise has been forged since the reforms of its oil industry in the 1980s and 1990s to respond to signs of a reduction in the productivity level of the oil and gas industry. The Company Law of the People's Republic of China was drafted based on the professionalization of the oil industry with China National Petrochemical Corporation (SINOPEC) and China National Petroleum Corporation (CNPC).

After this period of property reorganization, the central Government has kept 106 State enterprises in its organization chart, 47 of which were in Fortune Global 500 list in 2014. In 2013, the major SOEs (yangqi) controlled more than US\$ 5.6 trillion in assets, US\$ 690 billion of which were overseas (LEUTERT, 2016). These companies hold vice-ministerial level (fubuji), which gives their executives a political elite status, occupying prominent positions in the Chinese Government. Better administrative positions depend on their ability to achieve benefits for their respective state-owned enterprises, even if in competition with other industries. The space of the Communist Party of China (CPC) in the corporate decision-making field is quite significant, which in conventional theory is only considered in terms of being 'good' or 'bad' for market efficiency. That is why business in China is considered as incomplete or inefficient.

In China, the role of the energy sector in its long-term economic development process is largely exercised or implemented in collaboration with large state-owned enterprises. Sinopec, China's largest state-owned enterprise and the fourth largest company in the world, based on Fortune Global 500 of 2016, has been forged within the limits of state planning. These limits can be understood as market delimitation and definition of the very structure and competition pattern of such market, always follo- 
wing economic development needs, as it has happened with the energy matrix. Since the late 1990s, with the restructuring of the oil industry, Sinopec has been divided into the Sinopec Group and Sinopec Corp. In theory, the latter deals with core businesses and reports to the former, which deals with non-core businesses and reports directly to the State Council. In practice, a precise separation between them is quite difficult due to the confusing information published about it and even the peculiar characteristics of what in the West is understood as Chinese privatization. Understanding the evolution of the large Chinese company, especially in the oil sector, is relevant to understanding the country's development strategies.

Therefore, in this paper, we believe that in order to comprehend the activity of Chinese companies abroad, one must first understand the companies themselves. For example, the 13th Five-Year Plan formalizes initiatives such as One Belt, One Road and Made in China 2025, which are basically articulated within Chinese state-owned enterprises. Since the promulgation of these plans, scholars such as Majerowicz and Medeiros (2018) have pointed to the general orientation of Chinese policy to reach deeper positions in the international value chain. Thus, the choice of SINOPEC as the object of study for this paper occurred for four main reasons: (i) its investments in South American countries, such as Repsol-SINOPEC, especially its Brazilian pre-salt projects; (ii) is one of the oldest Chinese companies and has experienced - as well as other large Chinese companies in the oil sector - structural transformations ('corporatization'), internationalization and, more recently, technological modernization and (iii) productive relationship confronts it with guaranteed access to oil and price stability in China and (iv) the company has built a strategic organizational policy to respond to changes in the Chinese domestic market as well as international competition requirements. The main objective of this paper is to analyze Sinopec, using the following elements: (i) theoretical review of the Chinese oil industry and the Chinese state-owned enterprise and (ii) annual Sinopec reports and Xinhua network reportage, as well as notes published on the State Council website. In addition to this introduction and the final considerations, this paper is divided into two main sections: (i) it will present the general context of the oil and petrochemical industry in China and (ii) analyze the essential aspects of the evolution of Sinopec within the Chinese development strategy.

Company and national development strategy: oil and gas industry in China

In 2011, China became the world's largest energy consumer and the second-largest oil consumer, coming from a scenario that began in 1993 when it became a net oil importer. Estimates from the International Energy Agency (IEA) currently indicate that $85 \%$ of China's domestic demand is met by imports, even after having remained as one of the largest producers throughout the 1960s and 1970s. In 2006, its oil consumption was 353 million tons with persistent annual increases, until it reached 578 million tons in 2016. Production did not keep pace with this growth. In 
3. It is what a given country can reasonably count as quantities of oil available to be marketed ('commercially recoverable') from a given date. The exploration of these deposits will depend on the economic conditions, the operational methods, as well as on governmental regulations
2006, Chinese oil production was 184 million tons; in 2016, the country produced 199.7 million tons of oil. In addition, its proven reserves ${ }^{3}$ totaled 16.4 billion barrels in 1996, increasing to 20.2 billion barrels in 2006 and 25.7 billion barrels in 2016 (BP, 2017). The level of proven reserves in China has not grown much over the years, which may have been one of the key variables in the definition of the sector's development strategies.

Adapting the planned rates of economic growth, changes in the population's consumption patterns, as well as the development and international presence guidelines expressed in successive five-year plans to the functioning of the energy sector is a challenge. These challenges are not limited to the institutional structure of China's energy industry, after all, supply and energy efficiency are completely attached to the support for the country's economic development model. Aspects such as conservation, emission reduction, and use efficiency increase make up the most recent premise of the country's energy policy. At the beginning of the 21st century, imported oil accounted for $32 \%$ of domestic consumption, and in 2012, it increased to $57 \%$. Oil and gas transportation challenges have been overcome with an increase in gas pipelines, although geopolitical risks remain high. In 2012, there were 70 thousand kilometers for oil and 40 thousand for natural gas. In this regard, agreements with neighboring countries and state support for the construction of transport logistics are key (MEIDAN, 2016).

In such scenario, large national oil companies continue to be the main agents in implementing the guidelines included in the five-year plans, even though they are subject to a greater number of requirements. This section seeks to clarify the construction of large Chinese oil companies and the institutional structure of this industry.

Resource allocation through the formation of state-owned corporations and the oil and gas industry in China

Initially, during the Maoist period, the Chinese oil and gas industry was erected under the premise of energy self-sufficiency. The discovery of oil in northwestern China in the late 1950s, more specifically in Daqing, located in the Heilongjiang Province, represented a solution to the interruption of technical and economic cooperation with the USSR given the Sino-Soviet conflict. The share of oil in China's energy matrix went from $2.5 \%$ in 1960 to $13.5 \%$ in 1968 and this industry has become a pillar industry within the PRC's state planning. The trajectory of the Daqing well has become a model ('spirit of Daqing') to China's long-sought productive development and led to the emergence of a political oil elite - 'oil class' -, which put the matters of this industry in evidence in the ensuing five-year plans - thus, fiscal and political resources -, at least until the Cultural Revolution (LIEBERTHAL; OKSENBERG, 1988). Regarding the government-company relationship of this period, Nolan (2001) emphasizes that there have always been doubts about the Daqing format, i.e., whether it should be a company or an oil well.

Despite a crippling interregnum for the 'oil class' (1966-1976), coal and oil production expanded annually at a 13\% average rate, and by 1978 the country was the fourth largest energy producer in the world and the third largest consumer. Industrialization and urbanization on an intensi- 
ve scale boosted the demand for oil, although there was a logistical mismatch between oil production and exploration and the possibility of meeting the demand of industrial consumer centers. It was estimated that in the 1980s China would become the world's oil giant. However, in 1979, production grew by only $2 \%$, and between 1979 and 1983, it stagnated at 100 million tons, while investment in the sector fell. In 1984, production increased again to 137 million tons, and the country, contrary to the World Bank predictions, exported the largest volumes in its history (CHOW, 1991).

Thus, in the Maoist period (1949-1976), the oil industry experienced considerable advances in exploration, extraction, as well as in transportation and conservation techniques, though using obsolete techniques compared to developed countries. At the end of the Cultural Revolution, the political oil class recovered its participation, but investments in the sector remained low. Even with a significant recovery of the volumes produced, a short-term institutional action was observed in 1984. The concern consisted in maximizing short-term production, which prevented China from facing its geological and technological limitation. Supply and demand were determined by quotas, product prices were kept low and oil wells were not allowed to withhold revenues.

Incentives of productive units to increase their productivity were minimal, and they remained dependent on the central government to make new investments. In order to meet the demand for industrialization and urbanization deepened by the 1978 reforms, new oil wells would have to be drilled, and exploration techniques would have to be improved. Chow (1991) believes that throughout the 1980s the State Council has sought to correct the policy error of the 1970s, expanding exploration efforts in order to increase the country's reserves. The premise of self-sufficiency shifted to decentralization and corporatization in order to become a business-oriented policy.

All oil exploration, production and refinery construction activities were under the direct control of the Ministry of Petroleum Industry (MPI). State planning organized or centralized decisions and operations of production, transportation, administration and marketing of oil and its by-products, as well as exploration campaigns and provision of state financial resources (ZHANG, 2004). Until the 1980s, China's petroleum and petrochemical sector operated under a single large company run by the central ministries. Domestic prices were not formed according to the rules of the international market. Two major changes were conducted in the early 1980s, the decentralization of control, with the creation of large corporate groups, and the introduction of the responsibility system, following the example of agriculture.

Chinese oil companies used to play the role of 'administrative entities', more so than of 'economic entities'. The Central State Council maintained its authority over pricing, production and distribution targets for oil products, as well as strategic investment decision-making (ZHANG, 2004). With reforms toward price liberalization, labor and production costs started to rise and companies incurred higher costs, while having to act to contain the ongoing inflationary process. The scenario presented 
on the occasion of the 7th Five-Year Plan justified that, in 1989, the State Council decided that the sector would undergo further reforms, which should be more gradual and imply greater state control (KONG, 2010).

The State Council opted for a reform of the institutional structure of its huge sector, instead of assuming a great risk under a big contract system, in which companies would have to produce $2 \mathrm{mb} / \mathrm{d}$ or 100 million tons. The first stage consisted of the creation of two large companies: (CNPC) and (Sinopec) and a smaller one, the (CNOOC). In 1983, Sinopec (downstream) was created through a merger of the Ministry of Petroleum Industry (MPI) and the Ministry of Chemical Industry (MCI), maintaining a significant part of the bureaucratic cadre of both ministries in its management. It was a ministerial-level company under the direct supervision and control of the State Council. Its responsibility was to formulate refining and petrochemical policies - including the development of resource allocation and pricing plans -, besides producing to serve the domestic market. Sinopec was meant to be centralized as a modern global company, while its subordinate companies maintained great autonomy and developed a corporation identity in the opposite direction of their parent company.

In this context, in order to respond both to the weakening of the oil industry and to the rise in inflation that contributed to the 1989 protests, there was a period of intense discussion and political experiments within the State Council and the leading group in the early 1990s, which gave rise to the large oil business groups. The decision to modernize the oil industry by dividing it in downstream, upstream and midstream did not fit the allocation of resources via market or the responsibility system. A two-tier system was introduced: refined products obtained from low-price crude oil should be sold at a low price and the rest at high prices (NOLAN, 2001). In 1993, price liberalization began, and the state stopped selling crude oil at the State Low Price. Faced with domestic demand pressures, the State Council allowed a growing commercialization outside state allocations, which resulted in a chaotic situation.

In the mid-1990s, consumption began to outpace production and refined products were also included in price liberalization. In 1997, the warning signal was triggered: international oil prices fell by $15 \%$ and domestic prices did follow the drop. Crude oil users were under great pressure, which encouraged smuggling. In 1998, there was little doubt that it was essential to increase competition among state-owned enterprises. In 1998, the MPI was reorganized into CNPC (upstream) at the bureaucratic level. CNPC then gained control over the assets that used to belong to the MPI, which was a milestone. A market orientation coordinated by the state was initiated among the companies in the sector. The price system for crude oil was changed and adapted to the international market. Reforms are now under way to separate government bureaucracy from business operations, including authorization to retain profits.

At the end of the 1990s, the central government began to restructure the functions and activities of the main state-owned enterprises to raise the production capacity of the oil industry. Company verticalization was one of the initiatives. Resources of large state-owned enterprises were 
reallocated to form big vertical groups that could perform other activities along the production chain. In addition, the State Council allowed the entry of foreign companies to function as an instrument of technological and managerial upgrading (FRISCHTAK; SOARES; O'CONNOR, 2013). In the face of the imminent competition with foreign companies, such as Exxon Mobil and British Petroleum, the Chinese government carried out the broadest restructuring of the petrochemical and oil industry. After the establishment of the Shanghai and Shenzhen Stock Exchanges in 1990, public listing was used since the mid-1990s as a controlled privatization tool of the state-owned enterprises that had a competitive potential and of the pillar industries. It was a period of overwhelming pragmatism, in which China's external presence and economic growth depended on the introduction of capitalist tools in both the business sector and the financial system ${ }^{4}$. Since 2001, China's capital market segmentation has been in A Shares, which refer only to Chinese companies and are listed in Renminbi. Only Chinese citizens can trade A Shares. H shares are traded on the Hong Kong stock exchange and play a growing role in the public listing of Chinese companies in general.

In 1999, Sinopec and CNPC assets were organized geographically within China: East and South for Sinopec. It transferred 19 petrochemical companies to CNPC, 14 of which were production units and 5 commercialization units. CNPC transferred 12 companies to Sinopec, 11 of which were in production and exploration. However, "The two giant companies were empowered by the State Council to make their own investment decisions, including forming joint ventures with foreign companies and raising their own financing". (NOLAN, 2001, p. 472). As in other pillar industries, there was a separation between core business activities, which became joint stock companies with listed shares - in this case, Sinopec Corp. - and non-core business activities, which became limited liability companies (subsidiaries).

The formation of large Chinese corporations (or corporatization process) occurred as competition with global companies became imminent, given national growth and development objectives. State-owned oil exploration and refining enterprises - such as the Sinopec case analyzed here - as well as metallurgical, electrical, and military equipment enterprises became large corporations, following the policy of mergers and acquisitions in the late 1990s, which included their subsidiaries and culminated in a vertical integration. These companies were internationalized in the 2000s (going out), after experiencing a new reform that made them business corporations and their subsidiaries limited liability companies.

With the administrative decentralization at the beginning of the 21st century, the State Council begins to face another challenge: large state-owned oil companies were integrated, while the central administration of the oil industry remained fragmented. In 2003, following these reforms, the sector experienced a phase in which the premise was the reconstruction of its productive capacity. The creation of the State-owned Assets Supervision and Administration Commission of the State Council (SASAC) in 2003, and the recentralization of the energy authority in 2008 with the creation of the National Energy Commission, were measures
4. We suggest reading Okazaki, Hattori and Takahashi (2011). 
aimed at regaining central government's control over the oil industry. SASAC is responsible for the executive control over the policy of the corporation (state-owned enterprises in general, in which they hold a stake). It has power upon regulation reforms regarding state-owned enterprises, strategic investment thinking, financial planning of the corporation, asset management, and property rights registry. SASAC may be considered as the representative of a modern system of property rights, i.e., an agent of state ownership in the large state-owned enterprises (CHEN, 2013). SASAC is subordinated to the State Council and to the Central Organization Department (CDO), which is controlled by the (CPC), and determines which CPC cadre will hold executive positions in Chinese state-owned enterprises.

On the other hand the entrepreneurial restructuring of the sector in 1998-1999 and the institutional restructuring in 2003 did not reach a final design. In the 2000s, large Chinese oil and gas companies became quite powerful inside China, gaining autonomy from the government within the framework of the going out policy. In 2011, Beijing reorganized the executive cadre of CNPC, CNOOC and Sinopec (groups), evidencing (or retaking) CPC's control over the firms of the industries that are pillar for the country's economic development. In the same way, they tried to control the enrichment of the executives of the oil companies and open the way, through a severe policy of fight against corruption, to promote a certain restructuring of the sector, so that the State Council would not have its action limited in the companies of the oil and gas industry. Finally, the 12th Five-Year Plan (2011-2015) established among its missions that the State Council should redistribute wealth from its corporate entities to families. The growth of large Chinese oil companies throughout the first decade of the twenty-first century has challenged the CPC's governance of SOEs and increased competition among these companies.

BRI, Made in China 2025, and the activity of Chinese state-owned enterprises: a new impulse for large state companies

The Belt and Road Initiative (BRI) was officially announced by Xi Jinping in 2015, but its design was launched in 2013. Since then, it has become China's key foreign policy project, especially within its Asian neighbors, as well as African and European countries. In fact, this initiative has led to increased investment by Chinese companies at a time of comparatively lower economic grow th rates (OCDE, 2018).

Formally, BRI consists of 6 (belt) routes or main corridors, namely: (i) New Eurasia Land Bridge (western China to the west of Russia); (ii) China-Mongolia-Russia (northwestern China to the southeast of Russia); (iii) China-Central Asia-West Asia (west of China to Turkey); (iv) China-Indochina Peninsula (southwest China to Singapore); (v) Bangladesh-China-India-Myanmar (southwest China to India) and (vi) China-Pakistan (west/south of China to Pakistan). The (Road) connection occurs through the following officially disclosed routes: (i) China-Indian Ocean-Africa-Mediterranean, (ii) China-Oceania-South Pacific and (iii) China-Europe-Arctic Ocean (CHINA, 2017). There are at least 68 countries involved with 270 projects signed, totaling US\$ 
900 billion. More than agreements for physical connection infrastructure projects, BRI is a multilateral organization between developed and developing countries around issues such as investment promotion and trade opening.

The initiative marks the 'dream of the great rejuvenation of the Chinese nation'. Not only because it revives the silk route of imperial China in the 21st century, but also because it establishes a structural change in the international insertion pattern of this economy. Made in China $2025^{5}$ can be understood as a complement to this initiative. The MDI was developed by the Chinese Academy of Engineering and the Chinese Academy of Sciences based on the German program Industrie 4.0 and consists of major projects aimed at making the Chinese industrial sector able to compete with advanced nations and face competition in wages with neighboring nations in Southeast Asia. Moving from 'factory of the world' to global industrial power and becoming a world power in industry research and development in 2049 is one of the main premises of the Chinese economic development project (EUROPEAN CHAMBER, 2017). Some of the major projects of MIC 2025 include building industry innovation centers, intelligent and sustainable manufacturing, innovation in disruptive equipment, such as electric vehicles, sustainable trains, etc. Projects of this size include 10 sectors considered key, such as aerospace equipment, robotics, electric and low consumption vehicles, electrical energy equipment (RIHO, 2015). Industry remains the engine of the country's economic growth, but it assumes that a world power must have a technologically developed industry.

In this context, companies, especially the state-owned ones, are challenged in terms of management techniques, the role of managers, and procedure standardization, i.e., they have to boost R\&D and production. The goal of diversifying the energy matrix and tightening the policies regarding large oil companies renews the strategic objectives for the industry. It includes hunting high executives and less communication between the top managers of these companies and the State Council, making the implementation of pricing and fuel certification policies stricter, and opening international competition in products such as natural gas. At the beginning of the first term of Xi Jinping, it was expected that his actions would be aimed at reforms to open the Chinese economy, which in fact did not happen. MIC 2025 maintains traditional Chinese industrial policy mechanisms - such as subsidies and state control - including mergers and acquisitions of state and private companies.

\section{Resource allocation via the formation of state corporations in China: the Sinopec case}

In order to understand the growth of Sinopec from 1983 to 2016, some notes are necessary: (i) the existence of a group and a corporation bearing the name Sinopec is the result of a property reform carried out in the 1990s, which separated operational activities and generation and retention of profits from the State Council - the corporation is constituted of core businesses, and the group of non-core ones (See section 2.1);
5. It was launched on May 19, 2015 as a newsletter by the State Council. 
6. The valuation of assets was carried out jointly by China United Assets Appraisal Corporation, Beijing Zhong Zheng Appraisal Company, CIECC Assets Appraisal Corporation and Zhong Fa International Properties Valuation Corporation ("registered valuers") in RMB $98,249,084,000$ (SINOPEC, 2009).

7. The shareholders and their respective equity stakes were as follows: China

Petrochemical Group Company (55.06\%), China Development Bank (10.12\%),

China Cinda Assets Management Corp $(10.05 \%)$, China Orient Management Corp (1.5\%) and China Huarong Asset Management Co. (0.68\%).

8. Hong Kong Securities Clearing Company Limited (HKSCC) and (ii) in the early 2000s, also following the strategy of increasing the efficiency of state-owned enterprises, it was transformed in a joint-stock company, i.e., the corporation China Petrochemical Corporation (Sinopec Group Company) was established by transferring its core businesses as well as its assets and shares to China Petroleum \& Chemical Corporation (referred to as, the corporation) ${ }^{6}$. There is a hierarchy between Sinopec Corp. and its subsidiaries, by which they operate in specialized segments within the oil industry, and Sinopec Corp. holds control over all of them. Therefore, (iii) the company that has to report to SASAC (i.e., the State Council) is Sinopec Group, the parent company of Sinopec Corp. It should be emphasized that this division, is not fully elucidated on their annual reports or even their respective websites.

Throughout the 2000s, Sinopec Corp. gained strength, becoming one of China's largest energy and chemical companies, integrated in upstream, midstream and downstream. Its main operations include exploration and production, transportation via pipelines, oil and natural gas marketing, petrochemicals, synthetic fibers, fertilizers, export and import, research and development (R\&D), development and implementation of information technology. Its operations in several segments, besides exploration and production, places it in a prominent position in terms of policy development and execution. The company's indicators and lines of action exert influence upon different productive sectors in terms of cost of life and national energy security, especially due to its energy efficiency.

Its shares listed on the Hong Kong stock exchange are denominated H-Shares, while the ones traded in Shenzhen and Shanghai are A-Shares. The shares of state-owned enterprises, such as its parent company China Petrochemical Corporation, are state-owned shares. In 2001, there were 5 shareholders with state-owned ${ }^{7}$ shares - Sinopec Group alone held $55 \%$ of interest - and other $5 \mathrm{H}$-Share shareholders - including HKSCC $^{8}$ with $10.33 \%$. In 2005, as part of the launch of the go global strategy, this composition changes considerably: China Petrochemical Corporation increases its stake to $71.2 \%$, and HKSCC becomes the only $\mathrm{H}$-share holder. The others become 4 state-owned funds and $4 \mathrm{~A}$-Share shareholders. Since 2008, China Petrochemical's shareholding has increased, surpassing $70 \%$, while HKSCC's reached more than $20 \%$ in 2016. The other A-Share shareholders take turns with interests that do not reach $2 \%$, each. It is noteworthy that as of 2013 the company's reports will include the names of A-Share shareholders in Mandarin, but no longer in English (HKSCC, 2014).

\section{Oligopoly and vertical integration as engines of sectorial development in China: Sinopec}

The change in the organizational structure of Sinopec in 1999, when the company became a joint-stock company with the creation of Sinopec Group, represented a fundamental step towards a new expansion trajectory. From the point of view of Sinopec, its vertical integration with CNPC allowed both companies to acquire complementary assets, R\&D 
capacity, and articulate their technology in upstream and downstream. Sinopec and CNPC joined the international oil and gas market. Both have grown their assets and come to dominate China's oil and gas industry. In practice, their financial autonomy has also allowed them to expand in the global market in terms of oil exploration and production opportunities, which especially over the course of the 2000s.

Regarding Figure 1, it is important to clarify that the core activities of Sinopec Corp. are in exploration and production, refining and chemistry, and marketing and distribution - and therefore it operates in midstream, upstream and downstream. Its main products are crude oil, petroleum derivatives, natural gas and chemical industry products (e.g., synthetic rubber, ethylene, etc.).

Figure 1 - Sinopec Corp.: Organizational structure

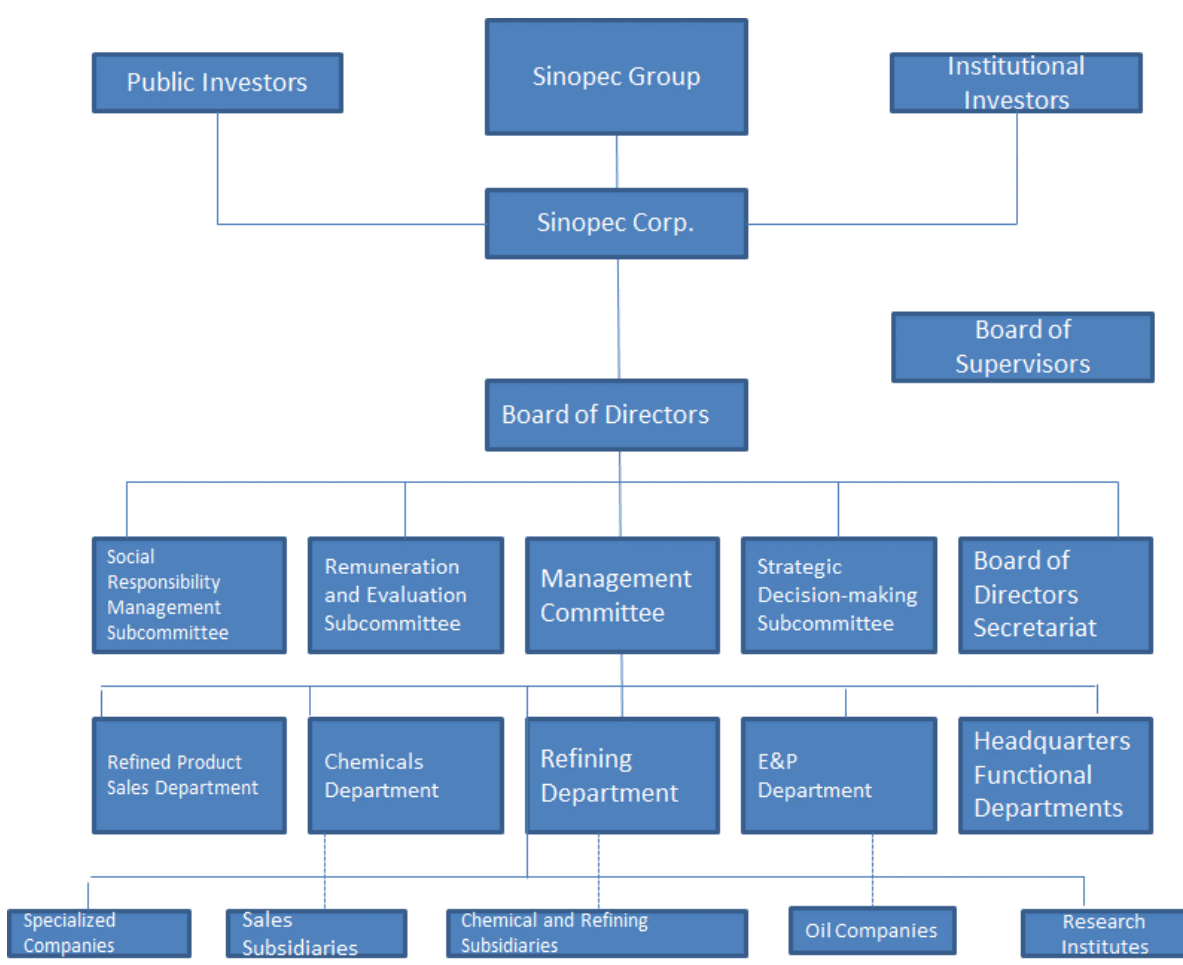

Source: Sinopec (2015).

The oil and gas industry operates in China under an oligopoly, in which price formation is determined by the State Council, and implementation and supervision by the NDRC. When it changed into a publicly traded company, its pricing and production decisions became more complex, since they had to ensure profitability and also comply with national price rules. Chart 1 shows some facts about its pricing policy in the Chinese scenario of the oil and gas market. Facts are based on information provided by the company itself. Considering the period 2001 to 2016, Sinopec Corp.'s pricing policy combined specific distribution strategies and diversification of natural gas production. Strategies included improving its logistics network and establishing contracts (coordination) with crude oil suppliers. Coordination has been Sinopec Corp.'s main strategy, due to the national scenario. 
Chart 1 - Segmentation of Sinopec Corp.'s market and distribution strategies

\begin{tabular}{|c|c|c|c|}
\hline Period & Domestic scenario & Sinopec's price policy & Market and distribution policy \\
\hline $2001-2006$ & $\begin{array}{l}\text { Refined products market was not well } \\
\text { developed. Disorganized competition. Pricing } \\
\text { mechanism for refined products made refine- } \\
\text { ries hesitate. } \\
\text { Domestic crude oil price followed interna- } \\
\text { tional prices. Demand for refined products } \\
\text { increased a lot. }\end{array}$ & $\begin{array}{l}\text { Coordination with other suppliers. Brought } \\
\text { difficulties with pricing mechanism to } \\
\text { central government. } \\
\text { Increased number of gas stations. Incre- } \\
\text { ased coordination with COCO companies } \\
\text { (company-owned and company-operated). }\end{array}$ & $\begin{array}{l}\text { Prices started to follow Singapore, New York } \\
\text { and Rotterdam international prices. State } \\
\text { Council set domestic market fluctuation at } \\
8 \% \text { instead of } 5 \% \text {. Could have increased } \\
\text { corporations autonomy to adjust prices. } \\
\text { Remained affected by pricing policy (spread } \\
\text { between domestic and international). }\end{array}$ \\
\hline 2008-2009 & $\begin{array}{l}\text { International prices rose significantly and } \\
\text { then fell sharply. Domestic petrochemical } \\
\text { prices fell sharply. In } 2009 \text {, demand for refined } \\
\text { products increased } 10.2 \% \text {. }\end{array}$ & $\begin{array}{l}\text { Effort to ensure supply. More intensive use } \\
\text { of pipelines. Positive changes in quality } \\
\text { standards. }\end{array}$ & Concern about meeting increased demand. \\
\hline 2012 & $\begin{array}{l}\text { Intensification of crude oil price fluctuations. } \\
\text { Number of vehicles in circulation increased. }\end{array}$ & $\begin{array}{l}\text { Increased its market share by using coordi- } \\
\text { nated logistics, improving quality control, } \\
\text { and implementing operational adjustments. }\end{array}$ & $\begin{array}{l}\text { Central government made } 8 \text { scheduled } \\
\text { price adjustments to reduce spread } \\
\text { between prices charged by corporations } \\
\text { and the ones indicated by the State Council } \\
\text { formula. }\end{array}$ \\
\hline 2013-2015 & $\begin{array}{l}\text { Domestic prices more subject to international } \\
\text { price fluctuation. Change in consumption } \\
\text { structure, continuous increase in demand for } \\
\text { higher quality refined products. Demand for } \\
\text { diesel fell considerably. }\end{array}$ & $\begin{array}{l}\text { Implementation of program for improved } \\
\text { quality control. Production of natural gas. } \\
\text { Increased pipeline network. }\end{array}$ & $\begin{array}{l}\text { Had to deal with crude oil price fluctua- } \\
\text { tions. Diversify energy sources. }\end{array}$ \\
\hline 2016 & $\begin{array}{l}\text { Demand for refined products increases timidly } \\
\text { - gasoline increased } 1.3 \% \text { and diesel } 2.2 \%\end{array}$ & $\begin{array}{l}\text { Followed strategy of investing in gas } \\
\text { pipelines and expanding sources. }\end{array}$ & Price setting following floor price. \\
\hline
\end{tabular}

Source: The authors (2017), based on company's annual reports.

As the information in Chart 1 indicates, the domestic demand for refined petroleum products not only increased but also became sophisticated, i.e., the Chinese urban population started to demand higher quality fuels. Even though price control by the State Council via NDRC has declined compared to 2001, it still persists. Fuel prices influence not only the cost of living of the population but also the cost of production. Thus, the role of a company in a socialist market economy, even if it has financial autonomy, is restricted by decision limits regarding price mechanisms.

The data in Figure 2 suggest that the fuel price index has always remained at higher levels than the general price index since 1998, when the oil and gas industry was restructured (corporatized). As a net importer of crude oil, the dependence of China's oil and gas industry on the international price trajectory is permanent, as the information in Chart 1 suggests. Its national oil and gas companies - Sinopec, CNPC, CNOOC, PetroChina - play a fundamental role in guaranteeing the supply of these products at a certain price. However, according to the data in Figure 2, fuel price trajectory has reached much higher levels than the general price index since 2000. Between 1994 and 1999, the fuel price index remained closer to the general price index. With the vertical integration of the sector, the distance between the fuel price index and the general price index became larger. Between 2000 and 2011, it can be said that fuel prices have always been higher than the general index. This distance decreased considerably since 2013, when the State Council changed its policy towards the sector. That is, although it is said (MEIDAN, 2016) that Xi Jinping's anti-corruption policy is mainly aimed at increasing the efficiency of companies in the sector, there are already perceptible results (Figure 2 ) regarding the cost of living of the population. 
Figure 2 - Evolution of general price index and general index of fuel prices in China (1994-2015)

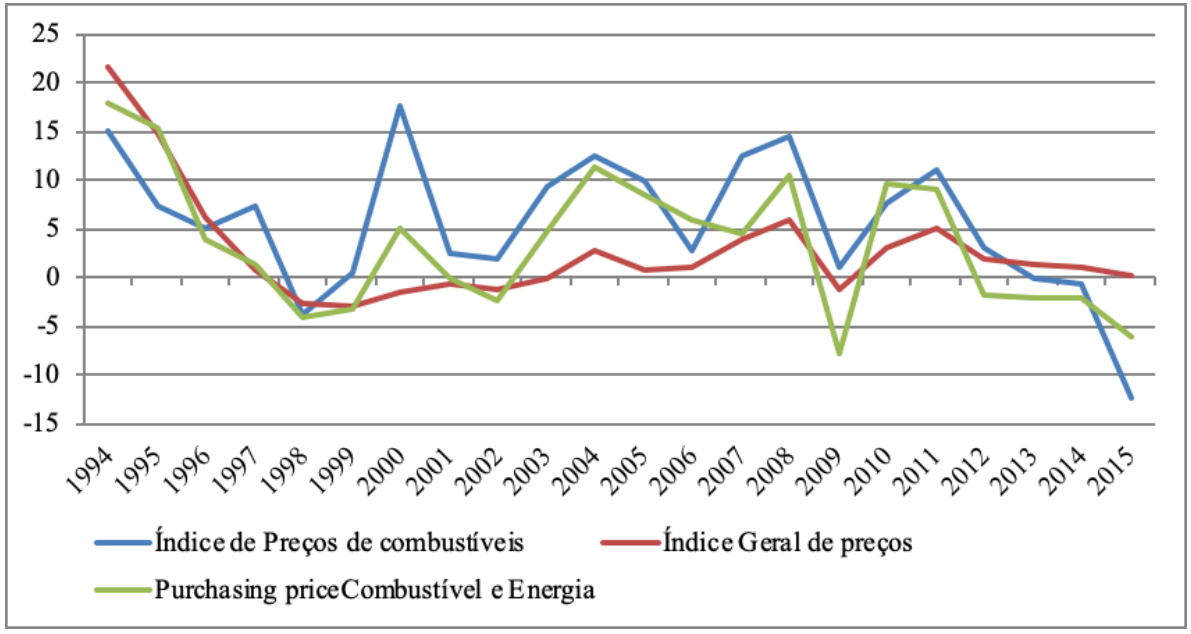

Source: The Authors (2017) based on China Statistical Yearbook (2016).

The multidimensional and departmentalized format of the large enterprise is studied for large traditionally established firms, which have accompanied and induced all major changes in the patterns of competition, market structure and sectoral innovations of capitalism. Chinese companies, such as SINOPEC, exhibit a complex structure, which can be linked to that traditional structure. However, its division in Sinopec Group and Sinopec Corp represents a link to both its growth strategies and national development policies. The Sinopec Group are related to the formulation of general policies of human resources, external affairs, science and technology, planning and development, among others. The corporation - Sinopec Corp -, in turn, is formed by the articulation between Sinopec Group, public and institutional investors (SOE's and the Chinese government). Its organization, its departments, reflects the implementation of the Sinopec Group guidelines, as outlined in Chart 1 reflect a upward trend in fuel and energy prices in China, which has led to pressures on Petroleum.

Energy development and national sovereignty: diversifying and meeting the demand

In this item, we seek to raise some indicators of SINOPEC Corp in terms of production growth and strategy. At the end of the 1990s Sinopec produced 0.78 million barrels per day (NOLAN, 2001). In 2008, the company was producing 322 million barrels (MMbbl) of crude oil per day, 371 million barrels or equivalent (MMBOE) of oil and gas and 293 billion cubic feet (BCF) of natural gas. Not to mention its refining capacity of 175 million tons in 2008, since refining is its original core business. Between 2001 and 2008, the company expanded considerably. On the other hand, between 2008 and 2016, the company significantly changed its production strategy. In the scope of the central government's goals of diversifying China's energy matrix, natural gas became the main 
product of Sinopec Corp. Its production increased to 766 billion cubic feet in 2016, at the expense of crude oil, which dropped to 303 million barrels. While CNPC's strategy is to integrate its activities and increase its market share in downstream, the main strategy of Sinopec Corp. is to acquire more assets in natural gas (EIA, 2015). Chemical products have also gained more space in its product portfolio, especially synthetic resin: it starts at 9 thousand tons in 2008 and reaches 15 thousand tons in 2016 (SINOPEC, 2009; 2017). The data in Table 1 provide evidence of the evolution trajectory of the production levels at Sinopec Corp. The company continues to be a leader in downstream.

Table 1 - Sinopec Corp.: exploration and production data (2008-2016)

\begin{tabular}{|l|l|l|l|l|l|l|l|}
\hline & 2008 & 2009 & 2010 & 2012 & 2014 & 2015 & 2016 \\
\hline Oil and gas (MMBOE) & 370.87 & 377.45 & 401.42 & 427.95 & 480.22 & 471.91 & 431.29 \\
\hline Crude Oil (MMbbl) & 322.02 & 327.62 & 327.85 & 328.28 & 360.73 & 349.47 & 303.51 \\
\hline Natural Gas (bcf) & 293.07 & 299.01 & 441.39 & 598.01 & 716.35 & 734.79 & 766.12 \\
\hline Reserves & \multicolumn{5}{|l|}{} \\
\hline Proven reserves of crude oil and natural gas (MMBOE) & 2,961 & 2,920 & 3,963 & 3,964 & $*$ & 2,243 & 1,552 \\
\hline Proven crude oil reserves (MMbbl) & 6,959 & 6,739 & 2,888 & 2,843 & $*$ & 2,243 & 1,552 \\
\hline Proven natural gas reserves (bcf) & 4,121 & 4,043 & 6,447 & 6,730 & $*$ & 7,570 & 7,178 \\
\hline
\end{tabular}

Source: Sinopec annual report several years.

*This year, data disclosure format was so detailed it was difficult to compile it for presentation.

Sinopec was one of the market instruments used to address the complexity of the country's supply and access to oil, and to diversify sources. Between 2008 and 2016, even in a scenario of oil price reduction, Sinopec Corp. maintained its investments in gas exploration projects, and oil exploration and production, including well discoveries in different regions of China. In 2012, the company increased its product mix, with a larger production of items such as gasoline, jet fuel and high value-added products (SINOPEC, 2013). This change happened due to fluctuations in the international oil price, which jeopardized the central government's goals of providing domestic energy supply.

The projects are in line with the assessment of Wang (2016) that the strategy of the large Chinese state-owned oil and gas companies, especially Sinopec, is to integrate oil and gas, petrochemical and renewable energy businesses. The company has expanded its oil and gas exploration and production (upstream) strategy. As Wang (2016) highlights, the development of upstream operations occurs in northern China, in the Shengli well, Tahe fields, and gas pipelines. The Mineral Resources Law of the People's Republic of China establishes that mineral resources belong to the State, property rights are state-owned and exercised by the State Council, and exploration licenses are granted by departments.

However, in 2013, Sinopec Corp. decided to postpone many of its planned downstream investments due to refinery overcapacity in China, along with serious environmental disputes. Figure 3 begins the historical data series in 2008, since the company's annual reports did not inclu- 
de information on its refining capacity until 2007. In those years - until 2008 - Sinopec Corp.'s refining operations relied primarily on crude oil imports or companies such as CNPC and PetroChina to meet the national demand for fossil fuels. In $2006,70 \%$ of its source of crude oil was imported (more than 100 million tons). The data in Figure 3 suggest that the volume of gasoline, kerosene and diesel sales has evolved above the production capacity of Sinopec Corp., and refining efficiency has been maintained at more than 95\% each year (SINOPEC, 2007).

Figure 3 - Sinopec Corp.: evolution of refining capacity in million tons (2008-2016)

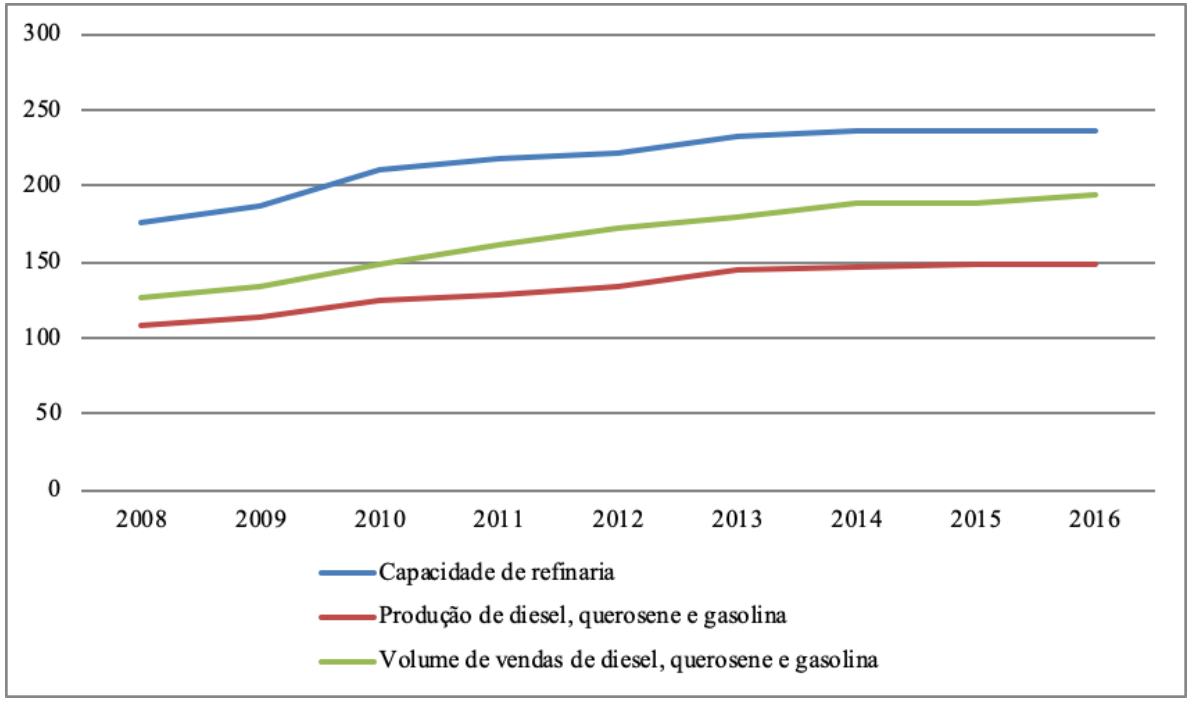

Source: The authors (2017), based on company's annual reports.

In this scenario, the State Council has encouraged competition in refining to meet the domestic demand. The atomization of refining is a constant reality in China. In the 1980s and 1990s, when the State Council tried a non-capitalist and modern company format, the number of refineries increased significantly, which reduced Sinopec Corp.'s refining capacity. More recently, this 'phenomenon' has happened again with small companies known as teapots - small refineries which, despite not having a letter of credit, have fostered the positive trade balance of oil and oil products in China. However, this state initiative to stimulate competition in refining has proved negative for its refining capacity.

It is correct to assume that the chemical products operation is the one that has experienced greater diversification. This decision of the corporation cannot be considered apart from the group. A State logistics and infrastructure initiative as Belt and Road (BRI), launched within the framework of the 'Chinese dream' or the 'rejuvenation of the nation' and which has been a symbol of the country's external presence, is an opportunity for the Chinese oil and gas industry to expand its capacity to transport imported oil.

In this article, we intend to deal with the elements that allow us to understand Sinopec - traditionally studied by Western authors as a purely inefficient company - as a multidimensional firm that has been consolidating itself as an administrative organization since the 
1980s, reflecting dynamic responses to the administrative structure to Chinese national economic development guidelines - here a different element compared to other oil companies. Still, the distribution of resources to Sinopec and its expansion of operations to different markets - natural gas and operation in new countries - reflect a management response focused on its growth. Expansion of the company has been built by productive opportunities for the construction of new productive capacities.

State-owned enterprise in China have always played an important role in the Chinese economy and maintain - despite the variety of readings on their influence on the direction of policies in the long-term accumulation strategy - their economic legitimacy in the country. The organizational structure of Sinopec, presented and discussed in this subsection, exposes a governance that responded to the role conferred to Sinopec in the integration to the international market, to forms of financing via share systems. Above all, it exposes a dynamic and pragmatic response from the central government regarding market ownership and structuring - demarcating competition between companies in the sector. In fact, state-owned enterprise constitutes, as Naughton and Tsai (2015) point out, the nucleus of "market socialism with Chinese characteristics", set out in the country's Constitution and reaffirmed in all official government and CPC documents. State-owned enterprise thus makes the structure of a governing party fruitful.

Profitability of the Chinese State-owned Enterprise vis-à-vis National Economic Development Strategies

In this subsection, we seek to present indicators related to the expansion of Sinopec, that is, its market and productive capacity building are articulated by its managerial capacity. In the 2000s, the Chinese government ostensibly encouraged the internationalization of oil companies to acquire and control oil exploration and development projects abroad. The fulfillment of its internal demand and the reduction of its dependence on the trajectory of international oil prices are some of its main motivations. Between 2003 and 2012, 85 Chinese investment projects in the world's oil and gas sector were announced, worth US\$ 130 billion. Sinopec Corp. had 35 announced projects (US\$ 65 billion), a significant participation in the State Council's internationalization strategy. Its internationalization is one of the instruments for China to ensure access to sources of crude oil. However, the data in Figure 4 suggest that the company's production of crude oil abroad is still much lower than its domestic production, not representing $15 \%$ of Sinopec Corp.'s total oil production in the period considered. From 2009 to 2013, this share was even lower, ranging from $8.2 \%$ to 5.6\% (SINOPEC, 2003; SINOPEC, 2014). 
Figure 4 - Evolution of the share of crude oil production abroad in relation to domestic production (2008-2016)

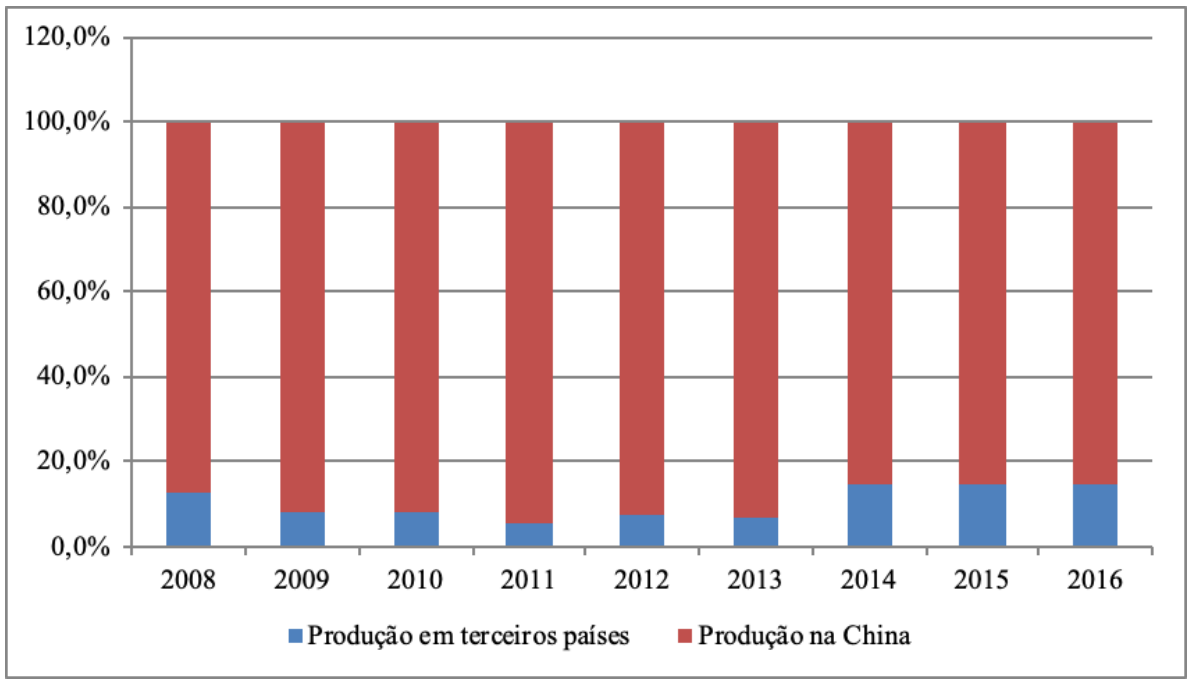

Source: The authors (2017), based on company's annual reports.

As of 2008, all the company's annual reports reinforce the commitment to its profit orientation, being attentive to the promotion of cost discipline and eliminating low-efficiency gas stations. Sinopec joins other Chinese state-owned enterprises whose operations must serve private and state interests (KAPLINSKY, MCCORNICK; MORRIS, 2007).

Although it is a public company, its growth is dependent on the Chinese long-term development strategies. In the last few years, some phases can be highlighted, namely: (1st) Strengthening of the go out strategy between 2005 and 2008; (2nd) Centralization and operational expansion of core businesses in 2008; (3rd) Peak of the period of expansion of investments abroad and of oil prices in 2009-2011. Expansion of chemicals and natural gas operations; (4th) Revision of management and strategies after grow th came to a halt, 2012-2015; (5th) Belt and Road Initiative (BRI), from 2016.

In 2008, Sinopec Corp. concentrated its core business activities by both centralizing sales and acquiring refinery, oil production, and gas pipeline assets from China Petrochemical Corp. There were also improvements in oil exploration and production technology - such as the development of the Puguang gas well. The company's operation scale increased significantly in 2008. Compared to 2005, its operating income increased $81.7 \%$, its total assets $40.8 \%$, and the distribution of dividends was positive (SINOPEC, 2009).

Figure 5 suggests that since 2003 the company became efficient in terms of its net assets structure compared to 1999-2002 levels, especially when associated with the period of high oil prices and the policy of funding its internationalization. From 2010 to 2015, the decline is constant until there is a rise in 2016. During this period, the company experienced a strong restriction within the price policy adopted by the State Council. The sector as a whole lost its communication channels with the State Council and companies were forced to implement poli- 
9. In its annual reports, this company presents its financial indicators - such as operating income, return, net assets, etc. - following the rules of China Accountig Standards for Business Enterprises and International Financial Reporting Standards (IFRS). That is, after presenting the information according to China's accounting standards, the company presents them based on IFRS standards. In 2006, the Ministry of Finance of the People's Republic of China (MOF) signed a new set of accounting standards - Accounting Standards for Business Enterprises (ASBEs) - which is convergent with IFRS international standards and also with Generally Accepted Accounting Principles of the United States (US GAAP). cies that raised their costs, such as reducing emissions and increasing fuel quality. The reversal of this negative scenario in 2016 was mainly due to the expansion and improvement of logistics in the crude oil marketing thanks to BRI.

Figure 5 - Sinopec Corp.: evolution of return on liquid assets ${ }^{9}$, \% (1999-2016)

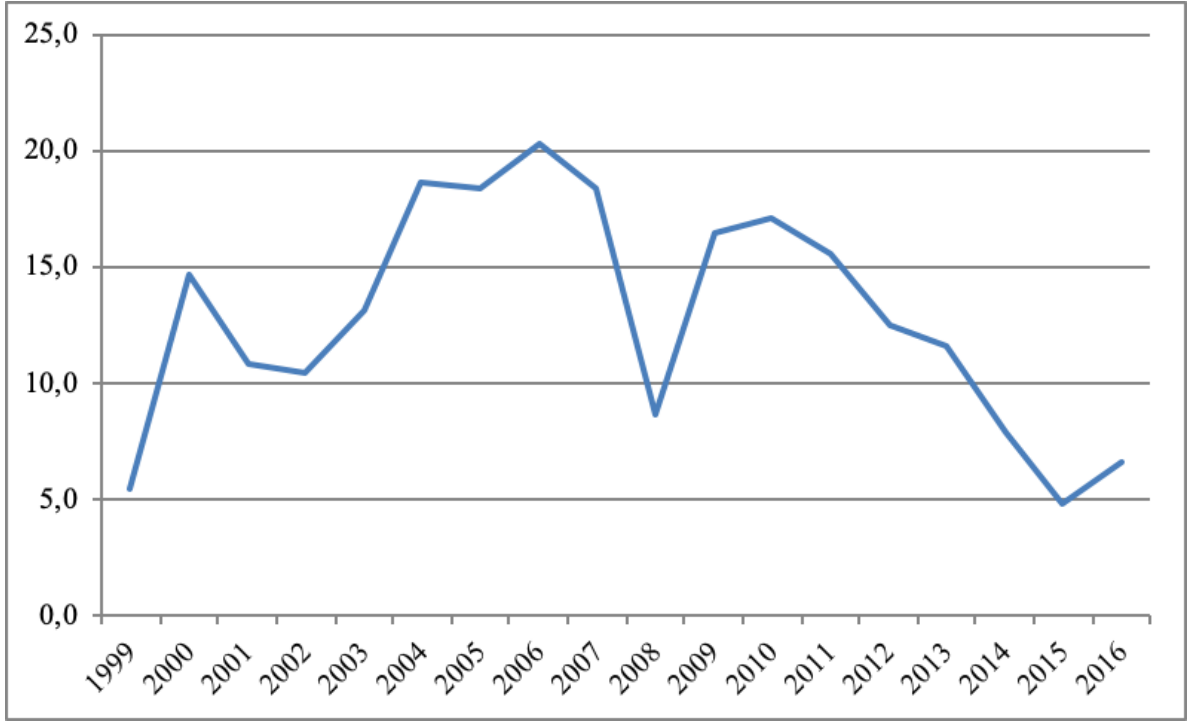

Source: The authors (2017), based on Sinopec Corp. annual reports.

In terms of net income, Figure 6 suggests that between 2008 and 2013 the company reached a considerable amount, while this upward trajectory began in 2003, after its public offering. Although the company has advanced in its operation (Figure 1) and market strategies, its profitability is closely linked to international oil price levels and to national policies. More specifically, the difference between domestic and international prices. In 2008 , the sharp fall in profitability shows this restriction.

Figure 6 - Evolution of Sinopec Corp. (1999-2016) net profit in RMB million

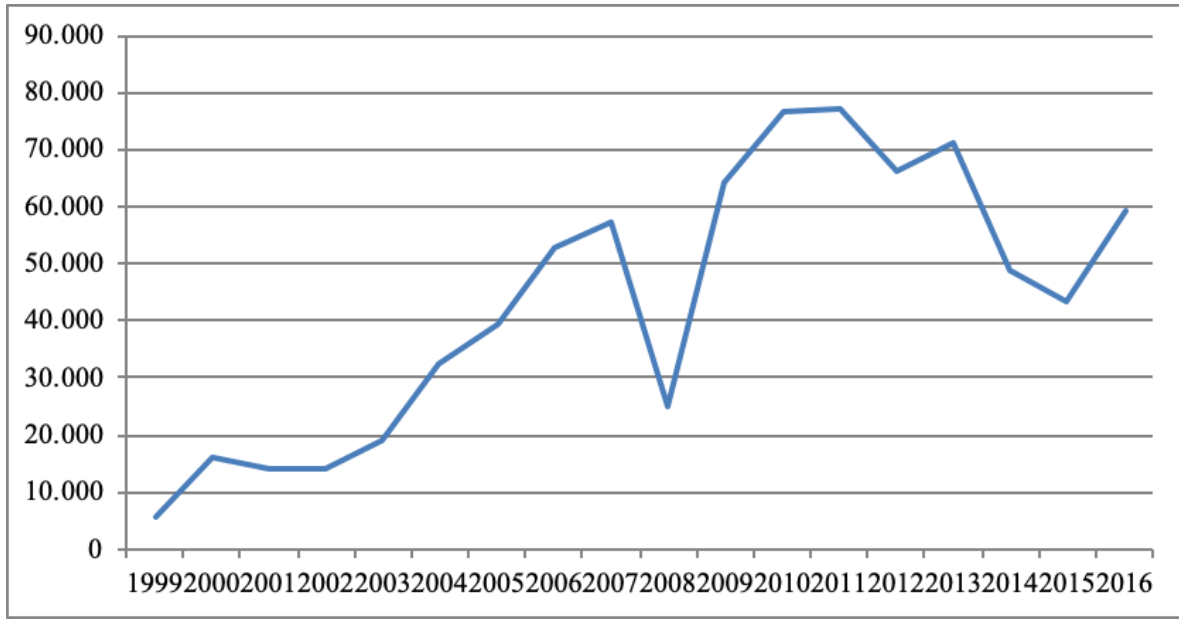

Source: The authors (2017), based on Sinopec Corp. annual reports. 
Between 2008 and 2012, the increase observed in company assets was basically due to a rise in oil prices. In 2012, the increase can also be explained by an expansion in the operation scale and the implementation of planned investments. Between 2013 and 2015, the company strengthened its strategy of investing in the quality and efficiency of its operations. Figure 7 suggests that, as Sinopec Corp.'s net profit grew steadily (2001-2007), shareholder composition changed in two ways: (i) Sinopec Group's shareholding increased and (ii) HKSCC's shareholding also increased. While HKSCC's interest increase was gradual, Sinopec Group's was abrupt. As early as 2003, its shareholding increased considerably. In the domestic scenario, the oil and gas industry faced a not so positive scenario in terms of purchasing price (Figure 2) and the profitability levels of Sinopec Corp. (Figure 6 and Figure 7) followed that trend. Even with the advances in exploration and production (Figure 2), the company's production of crude oil did not increase and its proven reserves maintained a significant decrease (Table 1). On the other hand, natural gas has become the main product of the company (Table 1 ).

Figure 7 - Evolution of net profit paid to Sinopec Corp. shareholders (1999-2016) in RMB million

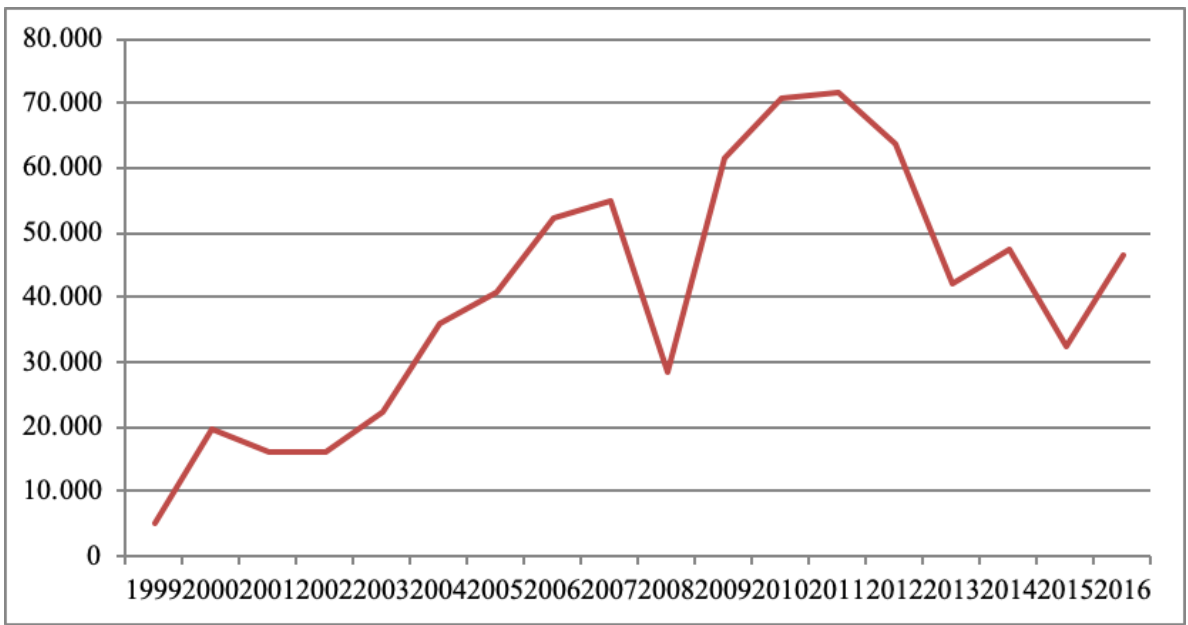

Source: The authors (2017), based on Sinopec Corp. annual reports.

The data in Figure 8 suggest that in the period of the most severe crisis, from 2012 to 2015 , the ratio between net income and number of employees remained more stable compared to the evolution of net income (Figure 6) and net income for shareholders (Figure 7). This movement occurred through an increase in employee layoffs. In 2012, there was a reduction of 1,024 employees; in 2013, there were 7,528 less employees compared to 2012; the same pattern was repeated in 2014 and 2015. Between 2001 and 2015, workforce reduction was taken seriously, with an average of 5,000 layoffs per year. However, in 2016 the number of employees reached a higher level than in 2001. 
Figure 8 - Evolution of the ratio between net profit and number of employees of Sinopec Corp. (2001-2016)

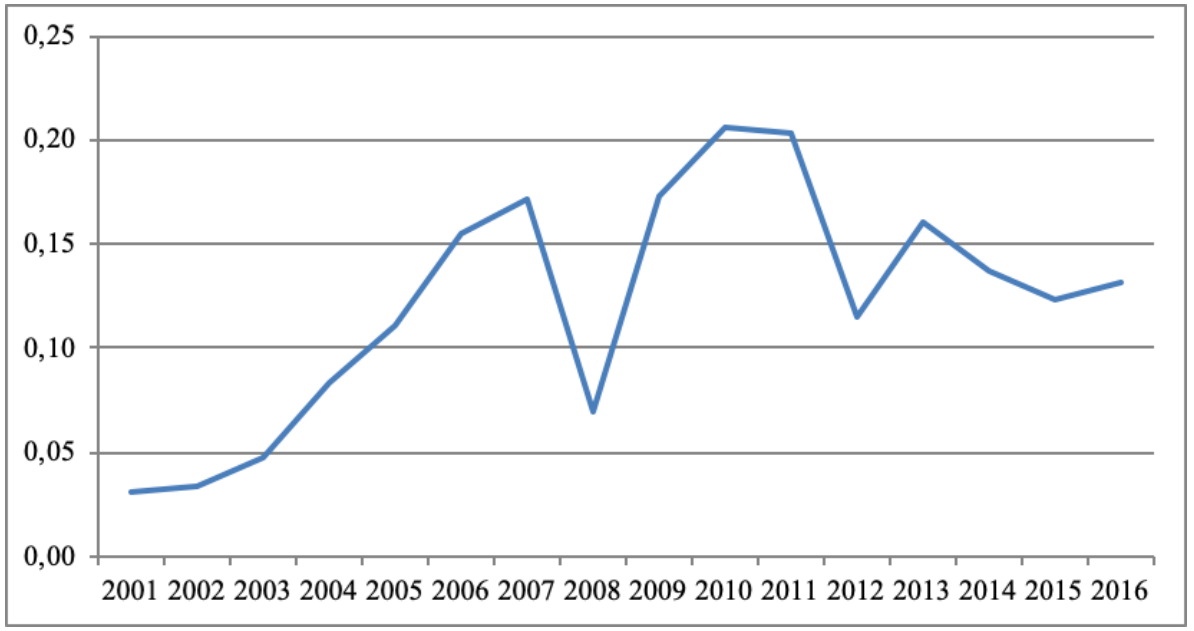

Source: The authors (2017), based on Sinopec Corp. annual reports.

Supporting a society that has become urban and industrialized implies more complex decisions on production and investment for oil and gas companies, and for Sinopec Corp. in particular. Since production is no longer centrally planned, the prospects of sales in the Chinese domestic market are uncertain. Its financial autonomy, evidenced by its transformation into a joint-stock company between the late 1990s and the early 2000s, faces a number of constraints posed both by the international price scenario and by the domestic scenario of the oil and gas sector. Comparing the trajectory of data on profitability and return on assets of Sinopec (Figures 6, 7 and 8) with data on prices - of fuels and in general - (Figure 2), it is noted that the company is still struggling to strengthen its competitiveness, besides international price fluctuations and national regulations. In fact, crude oil production has evolved much less than the production of natural gas and chemicals (Table 1), and Sinopec's production of crude oil abroad represents only a small part of its total production (Figure 4), which indicates the company has diversified its production in the oil and gas sector. Conventional notions that it is an inefficient company whose function is to stabilize prices and guarantee high employment levels do not hold up (Figure 7). On the other hand, since it is a company whose majority shareholder is a state-owned enterprise (Sinopec Group) that holds more than $70 \%$ stake, and whose directors are appointed by the CPC, it cannot be considered independent of the five-year plans.

Final considerations

Sinopec can be considered a profit-oriented and shareholder-driven business involving a series of industrial processes in diverse segments of petroleum and petrochemical products. It can also be considered a business with a hierarchical administration based on orders from executives. It is quite true that these executives are chosen within 
the framework of the CPC cadre, i.e., their guidelines for Sinopec Corp. are not always in fact designed for Sinopec Corp. It is possible to distinguish different hierarchical levels, even though there is a latent conflict in China over the remuneration of the executives of its state-owned enterprises - especially over salary differences. In general, the treatment given to Chinese companies in the Western literature is that of companies or inefficient or growing due to state financial and technological support. In this article, we sought to start a different perspective, namely, to point out that the great Chinese company - conglomerate or corporation, as it was called in this article - has its own codification of the strategies to be adopted, as well as follows general policy focused on its growth and expansion. On the other hand, they are state support, which especially for the financing of R\&D projects and internationalization represents a possible competitive gain. Possible because the environment for innovation in China may be less favorable to companies than its western competitors.

It should be noted that the company has developed an integrated petroleum engineering system for oil and gas exploration and production: prospecting, geophysics, drilling, well logging, mud logging, well bottom operation, oil facility construction and machine manufacturing. It is the largest in China in refining and marketing. It also controls gas stations and distribution centers. In R\&D activities, its focus is upstream exploration and production, refining and petrochemicals, while Sinopec and its subsidiaries independently develop specific technology.

A modern firm has two growth engines: (i) continuous - basically, growth produces more growth - and (ii) co-evolution - growth of the firm and industry. It becomes clear that the question is not only the emergence of the large modern enterprise, but also the emergence of industry, an environment that influences the enterprise in terms of its external resources. The industry is more subject to broader issues than the firm is. In the case of the Chinese oil industry, many aspects must be considered, but in these final considerations we would like to draw attention to the antitrust and innovation laws.

The growth of Sinopec Corp. cannot be considered as a result of its management capabilities alone. Its strategy of expanding assets in exploration and production - especially in gas -, including the discovery of new wells and the development of suitable technologies for its exploration, is clearly related to Chinese national strategies and to international competition. The challenges of management and profitability modernization are increasingly present, and their confrontation or solution depends on the policy guidelines of the State Council. If for some scholars, it is agreed that China is a capitalist country, structures like Sinopec contribute to raise doubts about this prognosis.

References

BP. BP Statistical Review of World Energy. June 2017. Available at: https://www.bp.com/content $/ \mathrm{dam} / \mathrm{bp} / \mathrm{en} /$ corporate/pdf/energy-economics/statistical-review-2017/bp-statistical-review-of-world-energy-2017-full-report.pdf. Accessed: 15 aug. 2017. 
CHEN, Duanjie. China's state-owned enterprises: how much do we know? From CNOOC to its siblings. SPP Research Papers, n. 6, 2013.

CHINA proposes 'blue economic passages' for maritime. China Daily. Available at: https:// www.chinadaily.com.cn/business/2017-06/21/content_29825517.htm. Accessed on 14 Apr. 2018.

CHINA Statistical Yearbook, 2016. http://www.stats.gov.cn/tjsj/ndsj/2016/indexeh.htm Accessed on 11 nov. 2018

CHOW, Larry Chuen-ho. The rise and fall of Chinese oil production in the 1980s. Energy Policy, n. 19, p. 869-878, 1991.

CINTRA, Maria Vital Paganini. A presença da China na América Latina no século XXI: suas estratégias e o impacto dessa relação para países e setores específicos. Dissertação (Mestrado) Universidade Federal do Rio de Janeiro, 2013.

EIA. Annual Energy Outlook 2015 - with projections to 2040, 2015. Available at: https://www. eia.gov/outlooks/aeo/pdf/0383(2015).pdf. Accesed: 08 sep. 2016.

EUROPEAN Chamber. China Manufacturing 2025: putting industrial policy ahead of market forces, 2017. Available at: http://docs.dpaq.de/12007-european_chamber_cm2025-en.pdf. Accessed: 10 sep. 2017.

FRISCHTAK, Claudio; SOARES, André; O'CONOR, Tania. Chinese investments in Brazil from 2007-2012: a review of recent trends. China-Brazil Business Council, 2013. Available at: http://www.cebc.org.br/sites/default/files/pesquisa_investimentos_chineses_2007-2012_-_ingles_1.pdf. Accessed: 20 sep. 2017.

Hong Kong Securities Clearing Company Limited (HKSCC). Annual Report. 2014. 212p.

KAPLINSKY, Raphael; MCCORMICK; MORRIS, Mike. The impact of China on Sub-Saharan Africa. IDS Working Paper 291, 2007.

KONG, Bo. China's International Petroleum Policy. California: Praeger Security International, 2010.

LEUTERT, Wendy. Challenges ahead in China's reform of State-owned enterprises. Asia Policy, n. 21 , p. 83-99, 2016

LIEBERTHAL, Kenneth; OKSENBERG, Michel. Policy Making in China: Leaders, Structures and Processes. New Jersey: Princeton University Press. 1988.

MAJEROWICZ, Esther; MEDEIROS, Carlos Aguiar de. "A política industrial chinesa na geopolítica da era da informação: o caso dos semicondutores". Revista de Economia. Contemporânea, v. 22, n. 1,2018

MEIDAN, Michal. The structure of China's oil industry: Past trends and future prospects. OIES Research Associate: OIES Paper: WPM 66, 2016.

NAUGHTON, Barry; TSAI, Kellee S. State Capitalism, Institutional Adaptation, and the Chinese Miracle. Cambridge; Cambridge University Press, 2015.

NOLAN, Peter. China and the Global Business Revolution. Basingstoke: Palgrave, 2001.

OECD. "The Belt and Road Initiative in the global trade, investment and finance landscape". In: OECD Business and Finance Outlook, 2018, OECD Publishing, Paris, Available at: https://doi. org/10.1787/bus_fin_out-2018-6-en. Accesed: 20 sep. 2019

OKAZAKI, Kumiko; HATTORI, Masazumi; TAKAHASHI, Wataru. The challenges confronting the banking system reform in China: an analysis in light of Japan's experience of financial liberalization. IMES Discussion Paper Series, n. 2011-E-6, 2011.

PINTO, Eduardo Costa; CINTRA, Marcos Antonio Macedo. América Latina e China: limites econômicos e políticos ao desenvolvimento. Texto para Discussão, 012, UFRJ, 1-33, 2015.

RIHO, Emiri. Strategic Vision and Outlook of 'Made in China 2025' (Part 1). Mizuho China Monthly, 18 aug. 2015 Available at: https://www.mizuhobank.com/fin_info/cndb/economics/ monthly/pdf/R512-0070-XF-0105.pdf. Accessed: 20 sep. 2017.

SINOPEC Corp. Annual Report and Accounts 2008, 2009. Available at: http://www.sinopec. com/listco/en/investor_centre/reports/2008/. Accessed: 27 may. 2018

SINOPEC Corp. Annual Report and Accounts 2012, 2013. Available at: http://www.sinopec. com/listco/en/investor_centre/reports/2012/ Accessed: 27 may. 2018

SINOPEC Corp. Annual Report and Accounts 2014, 2015. Available at: http://www.sinopec. com/listco/en/investor_centre/reports/2014/. Accessed: 27 may. 2018 
SINOPEC Corp. Annual Report and Accounts 2016, 2017. Available at: http://www.sinopec. com/listco/en/investor_centre/reports/2016/. Accessed: 27 may. 2018

WANG, Lei. China's crude oil and natural gas industry. The Oil \& Gas Conference. Denver, Colorado, 2016. Available at: http://www.theoilandgasconference.com/downloads_TOGC_2016/ China-Oil-and-Gas-Lei-Wang-PhD.pdf. Accessed: 20 jul. 2017.

ZHANG, Jin. Catch-up and Competitiveness in China: The case of large oil firms in the oil industry. The China Quarterly, n. 180, p. 1103-1104, 2004. 